\title{
Post COVID Challenges to the Tourism and Hospitality Industry: A Study on Bangladesh
}

\author{
Md. Nasir Mia ${ }^{1}$ and Kamrul Hassan ${ }^{2} *$ \\ ${ }^{1 \& 2}$ Dept. of Tourism and Hospitality Management, Faculty of Business Studies, University of Dhaka, Dhaka, Bangladesh. \\ *Correspondence: mkhassan@du.ac.bd (Dr. Md. Kamrul Hassan, Associate Professor, Dept. of Tourism and Hospitality \\ Management, University of Dhaka, Dhaka, Bangladesh).
}

\section{ABSTRACT}

The contagious virus (COVID-19) has severely affected the tourism and hospitality industry all over the world, including Bangladesh. It has affected both inbound and outbound tourism of the country. All kinds of tourism firms like hotels, motels, resorts, and transportations have been closed down. Many people have become jobless. The objective of the study includes the challenges that the tourism and hospitality industry will face after the COVID pandemic. Two-phased data collection methods are utilized to achieve their search aim. Primarily, ten variables are identified to measure post-COVID challenges to tourism based on available literature and informal qualitative interviews. Later, a questionnaire is developed for conducting a formal survey to identify post-COVID challenges. Based on empirical findings, this study has identified some postCOVID tourism challenges such as managing health security, dealing with congestions, charging higher prices for securing health safety, managing skilled employees, and arranging developed tourism management technologies. The study further finds that challenges may remain for the industry even after the pandemic. In order to mitigate the post-COVID challenges, it offers a few suggestions such as understanding the new needs of tourists after the pandemic, developing an information system for satisfying the requirements of new-normal situations, and building awareness to tourism stakeholders.

Keywords: Tourism service providers, Tourists, Hospitality Industry, COVID 19, and Challenges to tourism.

\section{INTRODUCTION:}

The outbreak of COVID 19, an infectious disease caused by SARS-CoV-2, has affected all the sectors around the world (Centeno \& Marquez, 2020; Uğur \& Akbiyık, 2020). The virus was first identified at Wuhan, Hubei in China in December 2019 (Mayo clinic, 2020). Gradually the number of affected people has increased throughout the world within a month. The crisis is taken as a 'public health emergency of glo bal concern' and declared as a pandemic by the World Health Organization on March 11, 2020. Around 200 countries are going through the pandemic (Bartik et al., 2020). Bangladesh is also affected by the pandemic UniversePG I www.universepg.com on March 3, 2020. It has spread out in every division with higher affected rate.

The tourism and hospitality industry of Bangladesh has been impacted severely (Begum et al., 2020; Davahli et al., 2020). Many local and foreign tours have been cancelled for COVID 19 (Ranasinghe et al., 2020). Supply-side of tourism industry like hotels, motels, restaurants, transportations are going through a devastating situation. Though some hotels, motels and transportations were opened in limited way, but people are very afraid of going out for travelling (WEF, 2020). The study has discussed the challenges 1oftourism and 
hospitality industry due to COVID and recommends some strategies to mitigate future challenges of tourism and hospitality industry. An intensive effort of the world academics has been made to monitor the situation of COVID-19's impact on the global and national tourism industry (Uğur \&Akbıyık, 2020). It is seen that many tourism firms (government and private) are conducting research on different issues of tourism and hospitality industry about the severity of coronavirus.

They have published articles based on impact of coronavirus on travel and tourism industry. Someone has conducted research to know the tourist satisfaction on different sectors of tourism during pandemic. But many of their searches like Schotte et al. (2021), ILOOECD, (2020), Shetty, (2021), and Panthhe \& Kokate, (2021) have done their work on developed countries' perspectives. A few researches on the impacts of COVID-19 have been done in Bangladesh (Nath et al., 2020; and Hafsa, 2020). The objectives of those studies were to explore the post COVID-19 challenges that are faced by the tourism stakeholders (tourists and businesses) in Bangladesh after the pandemic. Those researches have further provided some policy-guidelines to lessen the challenges arising out of the pandemic.

\section{Literature Review}

The coronavirus (SARS CoV-2) has engulfed the world. It has kept negative impact on every sector of the economy, education, culture, transportation, environment and services (Panthhe \& Kokate, 2021). The pandemic has spread in Bangladesh very quickly about a million people have been affected by the virus. The affected rate has increased day by day. A total of793, 693 people are affected, out of which 733,466 are recovered and 12,458 are dead (WHO, 2020). The number of death has later increased to 27713 as on October 12, 2021. The Fig 1 below shows the number of affected and the number of death during the research period (20 February 2020 to 15 May 2021).

\section{Effects of coronavirus on tourism industry}

Tour and travel is a worldwide trade with associate annual average rate of growth from $4 \%$ to $5 \%$ (Rume \& Islam, 2020). It is estimated that $8 \%$ of world GDP and $10 \%$ of the employment are generated by tourism industry (Khan, 2020).

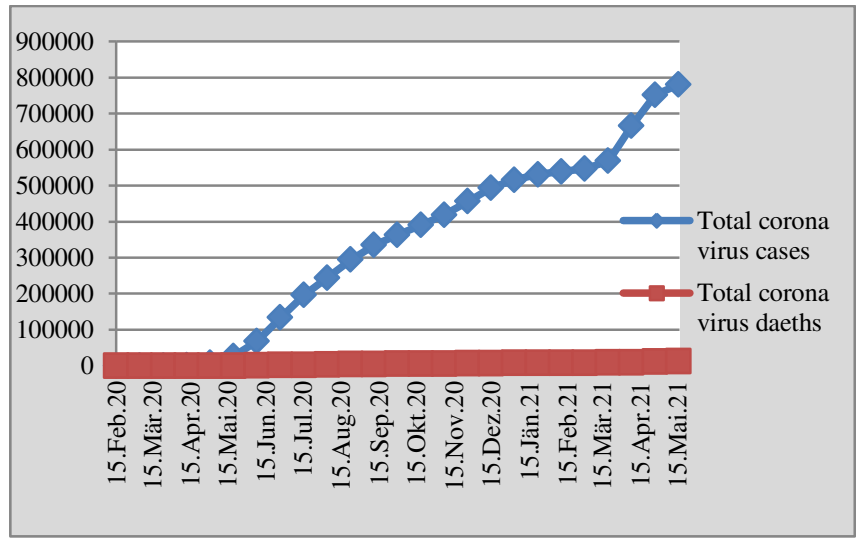

Fig 1: COVID cases and deaths in Bangladesh (20202021); Source: (Worldometer, 2021).

Now the industry is going through global pandemic which keeps negative impact on economy, health, education, and environment (Cetin, 2019). Every sector has faced irreparable loss throughout the year (Santos del Valle, 2020). There are 13\% people (households and individual level earnings) who have become unemployed. About 2, 00,000 institutions worldwide with40 million students have been closed down due to spread of this virus (Sakamoto et al., 2020). As such, an irreparable loss has occurred in society for the closure of educational institutions.

Airlines - Tourism sectors have been suffered acutely by shutting down air flights globally. The airlines sector has contributed $10.3 \%$ to the world GDP during 2019 (Dun \& Bradstreet, 2020). The industry is suffering from great challenges arising out of the ban of travel-restrictions on flight operations. Both domestic and international flights have been cancelled (Reza et al., 2020) throughout the world. It is predicted that airlines sector will experience a revenue loss of $\$ 163$ billion (IATA, 2020). There will be 25 million people who will be jobless who were engaged in different departments of airlines industry. The impacts of coronavirus on weekly flights of three Bangladeshi airlines are shown below in Fig 2.

Government has ordered to cancel all kinds of flights for the long time. But it has brought a great loss for the airlines industry. The Daily Star reported that Bangladeshi airlines industry is going to beating TK. 350 crores in revenue resulting from COVID-19. The below figure shows the poor flights number of three renowned airlines. 


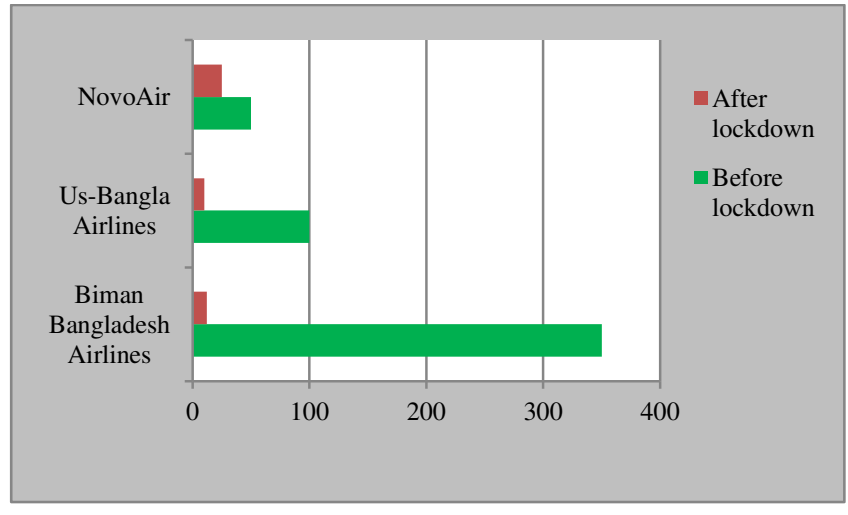

Fig 2: Impact of COVID 19 on the three airlines of Bangladesh (weekly flight numbers); Source: The daily star, (23 March 2020).

Hotels, resorts and restaurants - The hospitality sector (hotels, resorts, restaurants and bars) have been hit hard within the past weeks with most businesses closed and employees fired out. About 1, 00,000 employees are laid off (Hoque et al., 2020) from this sector. A major proportion of hotels occupancy and income comes from foreign guests in Bangladesh. Now the international visitors will not travel due to fear of the virus. Domestic tourists also do not visit spots. The reservations and occupancy rates of the four and fivestar hotels have decreased (Leith-eiser et al., 2020). The fluctuated occupancy rates of renowned hotels from April 2019 to 15 March 2020 are shown in the following Fig 3.

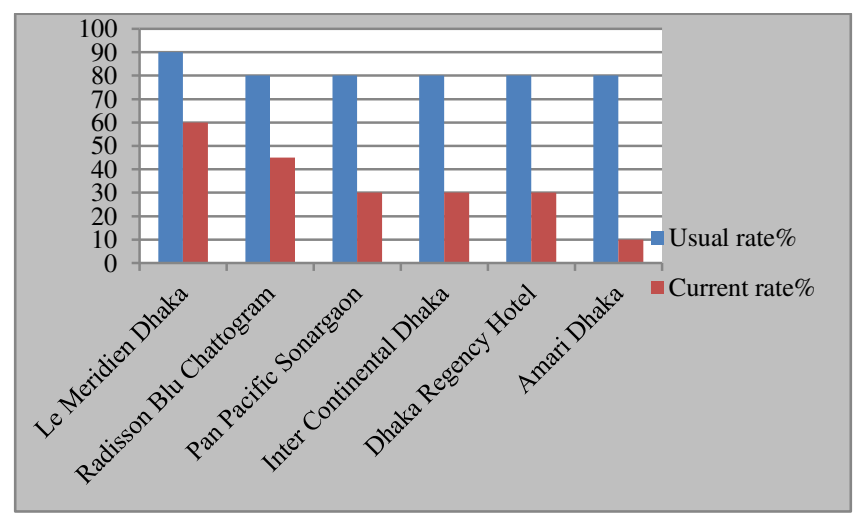

Fig 3: Occupancy rates of luxury hotels during COVID 19 in Bangladesh; Source: The daily star, (15 $5^{\text {th }}$ of March 2020).

According to the Secretary of Bangladesh International Hotels Association (2020), the usual occupancy rate was $80 \%$ but it has come down to a standard of $30 \%$ because of the pandemic. The occupancy rate of the Le Meridian Dhaka sank to $60 \%$ from $90 \%$ which bring a UniversePG I www.universepg.com great loss for the firm (Hafsa, 2020). The occupancy rate of "Amari Dhaka" sankto $10 \%$ and "The Six season Hotel" have lost TK. 1.5 crore which is devastating to the tourism and hospitality industry.

Employment and revenue generation - Tourism and hospitality industry is going through a great recession. The hotel sector lost around TK. 6 billion for the cancellation of booking (Vet et al., 2021). Tourism sector has started to fire out employees and reduced service items from the menu (Cetin, 2019). There are around 2000 people who become job-less from the airlines sector in Bangladesh (Rahman et al., 2021). To UNWTO (2020), Bangladesh is going to lose about US\$ 470 million due to COVID pandemic. Pacific Asia Travel Association (2020) forecasted that more than 0.3 million employee' will use their jobs. The estimated number of jobs at risk 1and loss of money for tourism/hospitality industry during COVID 19 is shown in the Fig 4.

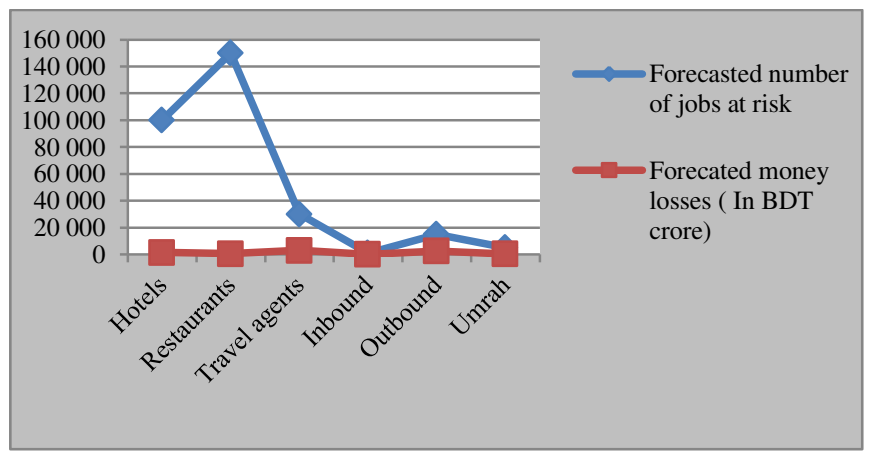

Fig 4: Forecasted losses of money and jobs in the tourism and hospitality industry (Source: Pacific Asia Travel Association, 2020).

The above Fig 4 describes the losses of money and the jobs risk of the tourism and hospitality industry. It can be seen that travel agent is going to loseTK.30 billion (3000 crores) for which 30,000 employees will be jobless (Huq \& Biswas, 2020). The other sectors have experienced more losses which are also exhibited in the above Fig 4.

\section{METHOLODOGY:}

The study is descriptive in nature which is comprised of both qualitative and quantitative data. Both primary and secondary sources are utilized to collect data. Primary sources provided major area of data. Interview and survey were used to collect primary data. An interview is conducted on 20 tourism stakeholders (tourism 
professionals, hoteliers, travel agents, airlines and tourists) through mail and over phone. Some issues have been identified from their insights about the post COVID challenges of tourism/hospitality industry. There search has further conducted an extensive review of literature to get insights about the impacts of corona virus on this industry. The identified issues are reconfirmed by dependable literatures like daily newspapers, journal articles, UNWTO news bulletin and reports, Pacific Asian Travel Association's (PATA) reports and other secondary sources.

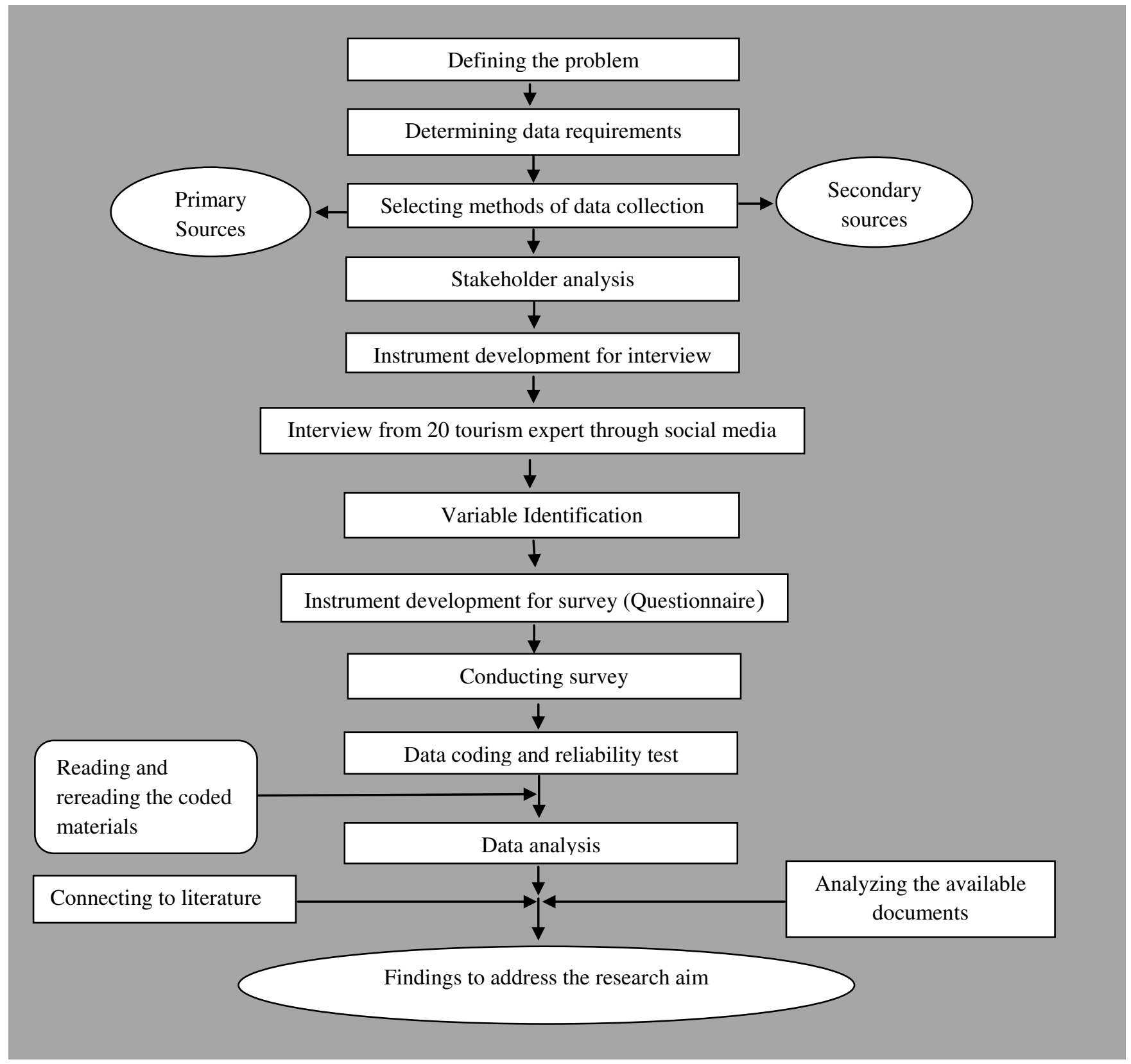

Fig 5: Data collection methods and techniques.

\section{Data collection methods and techniques}

A rigorous process is followed to collect and analyze the data. The research process is shown in Fig 5. An extensive review of literature has been conducted to assess the impacts of COVID-19 on this industry. Data have been sourced from the secondary sources such as artiUniversePG I www.universepg.com cles, reports, journals and newspapers. Then twenty tourism stakeholders had been chosen to conduct interview. Questions on four major issues were asked to the stakeholders on the impact of COVID-19 on this industry. Ten independent variables are identified through the interviews. These are given above - 
Dependent variable Y: Difficult to travel after COVID-19.

\section{Independent variables}

$\mathrm{X}_{1}$ : Worried to go out for health and safety issues

$\mathrm{X}_{2}$ : Reduced Income for lockdown

$\mathrm{X}_{3}$ : Feel very scared to attend any social gathering

$\mathrm{X}_{4}$ : Lack of time to travel after Pandemic

$\mathrm{X}_{5}$ : Visa processing is difficult to travel to foreign tourism sites

$\mathrm{X}_{6}$ : Unemployment can be the main reason for not travelling after pandemic

$\mathrm{X}_{7}$ : Extra burden to carry health protective equipment to visit tourism destination

$\mathrm{X}_{8}$ : Overcrowding in the tourism sites
$\mathrm{X}_{9}$ : Extra charge for health and safety protection

$\mathrm{X}_{10}$ : Service provider not being able in providing proper health and safety equipment

The dependent variable "Difficult to travel after COVID-19" (Y) basically has measured on the basis of challenges confronted both by tourists and tourism businesses after pandemic. The independents variables $\left(\mathrm{X}_{1}\right.$ to $\left.\mathrm{X}_{10}\right)$ are used to identifying their contribution to influence the dependent variable (Y). In this study, regression analysis is used as a statistical tool. A questionnaire was developed to survey 300 respondents. All the respondents were domestic tourists who traveled different tourism sites in Bangladesh. The demographic profiles of respondents are shown below in the Fig 6.
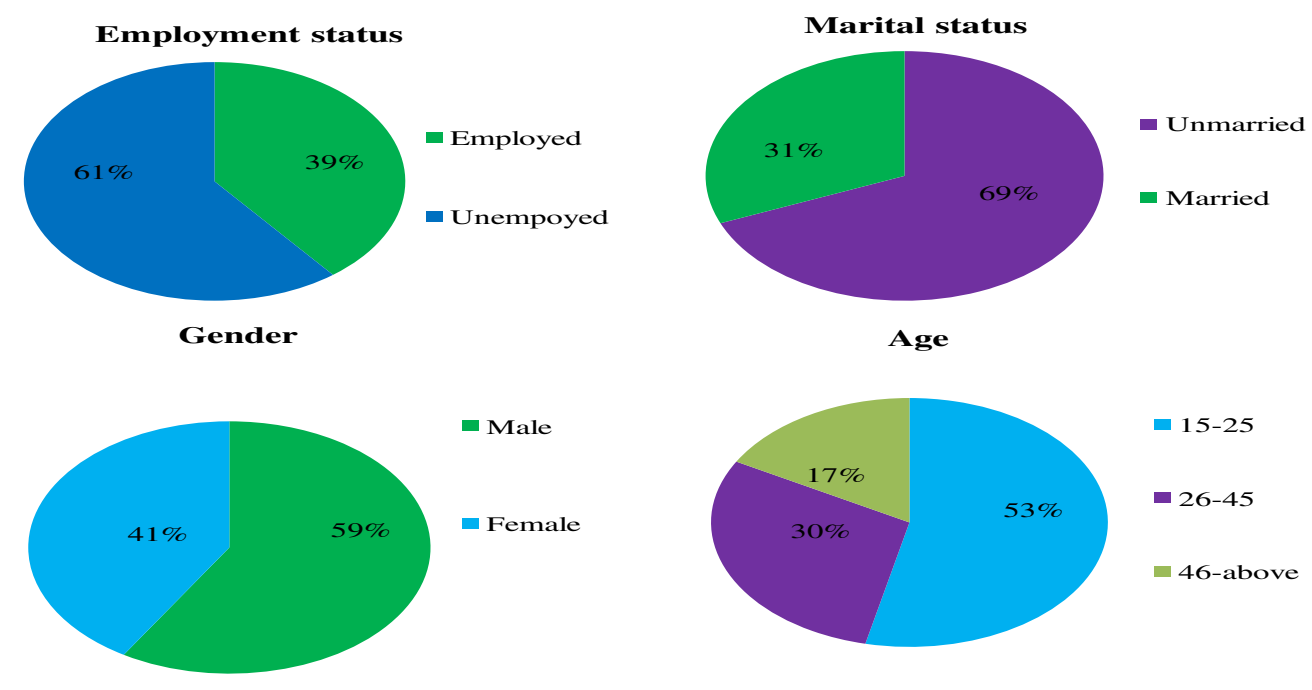

Fig 6: Number of respondents along with marital status, age and gender (Source: SPSS output).

The Fig 6 shows that the respondents of the survey are individual tourists. Among them 51\% were students, 39\% were jobholders and $10 \%$ were housewives. The percentages of male and female respondents are $59 \%$ and $41 \%$ respectively, and $69 \%$ were unmarried and $31 \%$ married. The age frequency of the respondents were $53 \%$ (15-25), 30\% (26-45) and 17\% (46-above).

\section{RESULTS AND FINDINGS:}

Reliability Test - The data were collected on the basis of dependent variable "Difficult to travel after COVID 19". Data "collected from the respondents" were analyzed by using "SPSS 26". Cronbach alpha and split techniques were utilized in testing the reliability of data. Table 1 has shown the results of the reliability test -

Table 1: Reliability Statistics (Using Cronbach Alpha technique); Source: SPSS output.

\begin{tabular}{|c|c|c|}
\hline $\begin{array}{c}\text { Cronbach } \\
\text { alpha }\end{array}$ & $\begin{array}{c}\text { Cranach's alpha based on } \\
\text { standardized items }\end{array}$ & $\mathbf{N}$ of items \\
\hline .784 & .789 & 11 \\
\hline
\end{tabular}

Cronbach alpha test was done to compute and verify the consistency of the items (Zikmund \& Babin, 2020). Cronbach alpha score should be 0.70 for any exploratory study to represent the reliability of data (Malhotra, 2010). The present score of 11 identified items is 0.784 that properly states the reliability of data. 


\section{Service providers' challenges}

Tourism service providers are the second important stakeholder after the tourists. They contribute more to the tourism and hospitality industry. Many challenges are faced by the services providers due to COVID 19. Participants from supply-side stakeholders (i.e. tourism service providers) have described some challenges which are hard to mitigate even after the pandemic. These are (a) overcrowding of tourists, (b) difficult to provide health and safety services, (c) extra cost to provide health and safety service, (d) structural alteration in the government and behavioral change of tourists, and (e) lack of investment and government's funding.

\section{Tourists' challenges}

Descriptive statistics: The Table 2 describes the mean value and the standard deviation of 10 independent variables in association with dependent one. It is observed that the mean value of dependent variable is 3.12, which indicates that tourists will face lower medium difficulties to travel after the COVID 19 pandemic. The mean value of others variables such as overcrowding of tourists at the tourism spots (4.01), lack of proper health and safety services (3.79), and extra charges for health and safety protection (3.75) are the some barriers to travel after COVID 19. Over- crowding of tourists at the spots has the highest 4.01 mean score indicating that tourists are less likely to travel in the overcrowded tourism destinations after pandemic.

\section{Regression analysis}

The coefficients of independent variables on dependent variable show that it is "Difficult to travel after COVID 19". This is shown in the Table 3 below.

$$
\begin{aligned}
& Y=-.511+.403 \mathrm{X}_{1}+.161 \mathrm{X}_{2}+(-.020) \mathrm{X}_{3}+.079 \mathrm{X}_{4}+.058 \\
& \mathrm{X}_{5}+(-.180) \mathrm{X}_{6}+.063 \mathrm{X}_{7}+.104 \mathrm{X}_{8}+.116 \mathrm{X}_{9}+(-.087) \mathrm{X}_{10} .
\end{aligned}
$$

It can be seen that the coefficient of 'Worried to go out for health and safety issues' $\left(\mathrm{X}_{1}\right)$, 'Reduced Income for lockdown' $\left(\mathrm{X}_{2}\right)$, and 'Unemployment can be the main for not travelling after pandemic' $\left(\mathrm{X}_{6}\right)$ have reached as $1 \%$ of significance. 'Visa processing is difficult to travel in foreign tourism spot' $\left(\mathrm{X}_{8}\right)$ has reached $6 \%$ level of significance. The scores of all the four coefficients show that tourists will be very reluctant to travel after pandemic. But tourists don't consider other variables as major restrictions to travel after pandemic. For that reasons, the significant level has come into below significant level. The four independent variables keep much more effect directly on the dependent variable. But other variables have less impact to de-motivate tourists to travel after COVID-19 (Allauddin et al., 2021).

\begin{tabular}{|c|c|c|c|}
\hline Items & Mean & Std. Deviation & $\mathbf{N}$ \\
\hline Difficult to travel after COVID 19 (Y) & 3.12 & 1.195 & 277 \\
\hline Worried to go out for health and safety issues & 3.78 & 1.053 & 277 \\
\hline Reduced Income for lockdown & 3.36 & 1.201 & 277 \\
\hline Feel very scared to attend any social gathering & 3.86 & .981 & 277 \\
\hline Lack of time to travel after Pandemic & 3.58 & 1.038 & 277 \\
\hline Visa processing will be difficult to travel foreign tourism sites & 3.26 & 1.210 & 277 \\
\hline Unemployment can be the main reason for not travelling after pandemic & 3.61 & 1.094 & 277 \\
\hline Extra burden to carry health protective equipment to visit tourism destination & 3.39 & 1.136 & 277 \\
\hline Overcrowded of tourists in the tourism sites & 4.01 & 1.056 & 277 \\
\hline Extra charged for health and safety protection & 3.75 & 1.026 & 277 \\
\hline Service provider not being able to provide proper health and safety equipment & 3.79 & .977 & 277 \\
\hline
\end{tabular}

Table 2: Descriptive statistics (Data source: Statistical package for social science; SPSS output).

Table 3: Regression of 'Difficult to travel after COVID 19' (Data source: Statistical package for social science; SPSS output).

\begin{tabular}{|c|c|c|c|c|c|}
\hline \multirow{2}{*}{ Variables } & \multicolumn{2}{|c|}{ Unstandardized Coefficients } & Standardized Coefficients & \multirow{2}{*}{ Sig. } \\
\cline { 2 - 4 } & B & Std. Error & Beta & & \\
\hline (Constant) & -.511 & .382 & & -1.339 & .182 \\
\hline Worried to go out for health and safety issues & .403 & .068 & .355 & 5.934 & .000 \\
\hline Reduced Income for lockdown & .161 & .061 & .161 & 2.641 & .009 \\
\hline
\end{tabular}




\begin{tabular}{|c|c|c|c|c|c|}
\hline Lack of time to travel after Pandemic & -.020 & .069 & -.017 & -.286 & .775 \\
\hline Overcrowded of tourists in the tourism sites. & .079 & .072 & .070 & 1.095 & .275 \\
\hline $\begin{array}{l}\text { Service provider not being able in providing } \\
\text { proper health and safety equipment. }\end{array}$ & .058 & .080 & .048 & .729 & .467 \\
\hline $\begin{array}{l}\text { Unemployment can be the main reason for not } \\
\text { travelling after pandemic }\end{array}$ & -.180 & .071 & -.165 & -2.531 & .012 \\
\hline Feel very scared to attend any social gathering. & .063 & .080 & .052 & .786 & .432 \\
\hline $\begin{array}{l}\text { Visa processing is difficult to travel in foreign } \\
\text { tourism sites. }\end{array}$ & .104 & .055 & .106 & 1.888 & .060 \\
\hline Extra charged for health and safety protection & .116 & .074 & .100 & 1.574 & .117 \\
\hline $\begin{array}{l}\text { Extra burden to carry health protective } \\
\text { equipment to visit any destination. }\end{array}$ & -.087 & .062 & -.083 & -1.398 & .163 \\
\hline
\end{tabular}

\section{Model summary}

The estimated mode has higher medium adjusted $\mathrm{R}$ value which indicates good fit for the regression data. The following Table 4 indicates that the value of $\mathrm{R}$ square is .657 and adjusted $\mathrm{R}$ square is .629. There is $65 \%$ of the total variability of tourists' problems which can be stated by the model summary.

Table 4: Model Summary (Data source: Statistical package for social science; SPSS output).

\begin{tabular}{|c|c|c|c|}
\hline $\mathbf{R}$ & $\begin{array}{c}\mathbf{R} \\
\text { Square }\end{array}$ & $\begin{array}{c}\text { Adjusted } \\
\text { R Square }\end{array}$ & $\begin{array}{c}\text { Std. Error of the } \\
\text { Estimate }\end{array}$ \\
\hline $.707(\mathrm{a})$ & .657 & .629 & .749 \\
\hline
\end{tabular}

ANOVA: As the ANOVA model (Table 5) shows that $\mathrm{F}$ test is significant. This is very logical to say that all independent variables have impact on the dependent variable (Difficult to travel after COVID 19). The estimated multiple regression models are more suitable for this study. Overall acceptability of the ' $B \mathrm{i}$ ' is tested by 'ANOVA' which also indicates the significance of the model.

Table 5: ANOVA (Data source: Statistical package for social science; SPSS output).

\begin{tabular}{|c|c|c|c|c|c|}
\hline $\begin{array}{c}\text { Sources of } \\
\text { Variation }\end{array}$ & $\begin{array}{c}\text { Sum of } \\
\text { Squares }\end{array}$ & df & Mean Square & F & Sig. \\
\hline Regression & 301.320 & 10 & 70.132 & 64.199 & .000 \\
\hline Residual & 292.983 & 266 & .801 & & \\
\hline Total & 394.303 & 276 & & & \\
\hline
\end{tabular}

\section{Tourism industry after the COVID-19}

The World Health Organization (WHO) has forecasted that the world doesn't turn into the normal situation (World Health Organization, 2020). People will survive to adjust with the coronavirus. It has put the industry into great challenges. The present research gives UniversePG I www.universepg.com a positive message for the industry in Bangladesh. It is understood that some people of Bangladesh travelled instead of being lockdown. They are very careless of the coronavirus. It is true that the brutality of coronavirus is less in Bangladesh than that of other tourism developed countries. Some respondents expressed that they have enough income, money, and employment to travel after pandemic. They also prioritize that they want to enjoy ecotourism, river tour-ism, cruise tourism, and village tourism that are less vulnerable due to COVID19. A number of 167 tourists (respondents) are agreed to visit after pandemic and 126 are disagreed to visit. The respondents replied positively but it bears a medium significance value. If they replied negatively that they are afraid of going out for safety issues, have more poor income, jobless, high exposure of corona, etc. The score of model summary would be high. It can show a great threat for the industry. But the medium value of $\mathrm{R}$ square (.657) which gives a good message for the industry indirectly.

\section{DISCUSSION:}

The analysis found that health and safety, decreased income of tourists due to COVID-19, overcrowding, and lengthy visa processing formalities are the main reasons for not traveling after the pandemic. Several researches like House, (2021), Shammi, (2021), and Monitor, (2020) support the problems that can be encountered after the pandemic. The problems to be faced by tourists are also problems for businesses. As the study focuses on the Post-COVID challenges to be faced by the industry; some propositions are discussed to mitigate those challenges: Firstly, tourism firms should understand the tourist's responses carefully after COVID-19 as the demand of tourists may significantly change. Tourism service providers should 
design their services according to the demand of the potential tourists. Tourists will no doubt be very worried about their physical issues. As such, it is essential to provide health and safety environment related services. Every tourism destination, airline, hotel should establish thermal scanner in their firms to ensure that their employees are free from coronavirus. They can provide hand sanitizer, mask and others protective tools to their guests (Alam \& Parveen, 2021). Tourists and employees can be affected by the virus at any time in destinations. Tourism management authorities should establish quarantine camps for tourists and employees in the high risk destinations. Tourists should also carry some protective equipment with them while they visit destination. Sometimes tourists are not very conscious regarding this issue. So every organization such as hotel, motel, restaurant and resort can develop their websites about the safety requirement that guest will carry with them while visiting tourist spots. The overcrowded tourist destination is another threat for the industry as well as tourists. Hotels, motels, resorts, travel agents and airlines can manage customers' overflow by shifting and distributing tourists to separate sites. They can take strategy to maintain carrying capacity of tourist sites. Service organizations also can enlarge their service spots in different places so that tourists don't gather much at the same place (ECLAC, 2020). Many domestic tourists will be eager to visit outside their country. Similarly, foreign tourists will also travel for different purposes in Bangladesh. Many tourists focused on lengthy visa processing formalities which will kill their valuable time. Visa processing should be made easier. It is found from the survey that many of the employees are very frustrated by being fired from their jobs during the corona period. Many travel and hospitality organizations have fired out many employees from their business. Tourism organizations can increase their service portfolio and recruit the old and ousted employees to the places after the pandemic (Padhi \& Triveni, 2020). It will again provide income to them. Some of them can be turned into tourists. Some tourists want to travel but they are very afraid of COVID-19. They feel very unsafe to visit tourist destinations. Anyway, tourism firms can make aware of their healthy and safe environment to motivate them. Reasonable prices are the matter of concern after pandemic. It is understood UniversePG I www.universepg.com that the majority of tourists are very conscious about the price level after COVID-19. As such, fair and reasonable price of tourist goods and services are important to motivate a good inflow of tourist customers at the destinations. Higher price can make tourists dissatisfied. Tourism service providers may adopt and apply value-based or demand-based pricing strategy. Business tourists who want to conduct their business activities including business deal, meeting and conference physically. But it will be risky for them. Virtual events and Hybrid events are the emerging solutions to these problems. People can attend virtual events, meetings and conferences easily (Davidoff-gore, 2020). Social and traditional media should ensure ethical and responsible use of their promotional sides. The entire tourism service related channel should remain open among tourism stake-holders in every nook and corner of Bangladesh. The regional public health authorities should be alert with a proactive strategic response. Lastly, national tourism bodies should repeatedly announce advice for tourists who are provided from UNWTO and WTTC. Both the national and local governments should collaborate on strategies to help the industry in emergency health crisis inside the country at this moment. Besides these, the industry can offer different exclusive items, maintain hygienic conditions of destination areas, quality of their products, and offer discounts and incentives. All tourism firms should come forward with investment in this industry. They should also develop a strategic plan and move forward to tackle the challenges of the industry.

\section{CONCLUSION:}

The paper has presented the challenges of the industry in Bangladesh arising out of COVID-19. On the basis of the interviews results and subsequent statistical analysis, it is originated that a few challenges can be faced by the service providers and tourists after pandemic. The findings show that people are very concern of their health and safety issues. They think that overcrowding of tourists will spread coronavirus among the tourists. Besides, it is found that many employees are fired out from their job from different sectors. They have poor income. They are less likely to travel even after pandemic. The research has also shown that tourists are very eager to visit eco-friendly 
destinations which have low exposure of corona virus. By analyzing the findings, it is understood that Bangladesh has a great opportunity to attract tourists by promoting eco-tourism, cruise tourism and village tourism. The study has faced some limitations due to the sudden outbreak of the pandemic. Firstly, it was impossible to collect data from larger and representative size of sample. Secondly, it was also difficult to conduct survey physically. Then some other res-trictions are faced such as unwillingness to give answer of the respondents for their secrecy, the poor net accessibility, difficulties to get more information from the secondary sources, tough to consider other issues relevant to the industry. To address these limitations, this research provides some guidelines for future research. Future researchers may conduct more conclusive research with larger sample. The researchers can also conduct descriptive type research to get more insights with large sample. Besides, research can be undertaken for the long term preventive measures to mitigate the loss of coronavirus in the industry. The fruitful research and implications of its result will be helpful to make the tourism and hospitality industry profitable all over the world.

\section{ACKNOWLEDGEMENT:}

The authors acknowledge the contribution of the interview participants and survey respondents.

\section{CONFLICTS OF INTEREST:}

The authors proclaim no conflict of interest with any other party while preparing this research article.

\section{REFERENCES:}

1) Alam, M., \& Parveen, R. (2021). "Covid-19 and Tourism", International Journal of Advanced Research, 9(4), 788-804. https://doi.org/10.21474/ijar01/12766

2) Allauddin, Rehman G, Zarkoon AK, Nasira B, and Khan IU. (2021). COVID-19 pandemic lockdown resulting in an unusual rectal foreign body in a young male. Eur. J. Med. Health Sci., 3(6), 132-135. https://doi.org/10.34104/ejmhs.021.01320135

3) Bartik, A., Bertrand, M., Cullen, Z. B., Glaeser, E. L., Luca, M., \& Stanton, C. (2020). "The impact of COVID-19 on small business outcomes and expectations [El impacto del COVID-
19 en pequeñas empresas respuestas y expectativas]", Proceedings of the National Academy of Sciences of the United States of America, 117(30), 1-41. https://pubmed.ncbi.nlm.nih.gov/32651281/

4) Begum, M., Farid, M. S., Alam, M. J., \& Barua, S. (2020). "COVID-19 and Bangladesh: SocioEconomic Analysis towards the Future Correspondence", Asian J. of Agricultural Extension, Economics \& Sociology, 143-155. https://doi.org/10.9734/ajaees/ 2020/v38i930417

5) Centeno, R. S., \& Marquez, J. P. (2020). How much did the Tourism Industry Lost? Estimating Earning Loss of Tourism in the Philippines. http://arxiv.org/abs/2004.09952

6) Cetin, G. (2019). International Tourism Highlights, $9^{\text {th }}$ Edition. https://doi.org/10.18111/9789284421152

7) Davahli, M. R., Karwowski, W., Sonmez, S., \& Apostolopoulos, Y. (2020). "The hospitality industry in the face of the COVID-19 pandemic: Current topics and research methods", International Journal of Environmental Research and Public Health, 17(20), 1-22.

https:// doi.org/10.3390/ijerph17207366

8) Davidoff-gore, S. (2020). COVID-19 and the State of Global Mobility in 2020.

https://publications.iom.int/system/files/pdf/covid19-and-the-state-of-global.pdf

9) Dun \& Bradstreet, (2020). Business impact of the coronavirus ( COVID-19) on regional logistics, July, 2.

https://www.dnb.com/content/dam/english/econom ic-and-industry-insight/DNB_Business_Impact_of _the_Coronavirus_US.pdf

10) ECLAC, (2020). The effects of the coronavirus disease (COVID-19) pandemic on international trade and logistics, 6, 7.

https://www.cepal.org/en/publications/45878-effec ts-coronavirus-disease-covid-19-pandemic-internat ional-trade-and-logistics

11) Hafsa, S. (2020). "Impacts of COVID-19 Pandemic on Tourism \& Hospitality Industry in Bangladesh". 19 (December 2019). https://papers.ssrn.com/sol3/papers. cfm?abstract $\underline{\mathrm{id}=3659196}$

12) Hoque, A., Shikha, F. A., Hasanat, M. W., Arif, 
I., \& Abu Bakar Abdul Hamid, (2020). "The Effect of Coronavirus (COVID-19) in the Tourism Industry", Asian J. of Multi-disci.Stud, 3(1). https://asianjournal.org/online/index.php/ajms/arti cle/view/213

13) House, M. (2021). Tourism and COVID-19: Mapping a Way Forward for Small States. December 2020.

https://thecommonwealth.org/sites/default/files/inli ne/Mapping_a_Way_Forward_for_Small_States_ UPDF.pdf

14) Huq, S., \& Biswas, R. K. (2020). COVID-19 in Bangladesh: Data deficiency to delayed decision. Journal of Global Health, 10(1), 1-3. https://doi.org/10.7189/jogh.10.010342

15) ILO-OECD, (2020). The impact of the COVID19 pandemic on jobs and incomes in G20 economies, 46.

https://www.ilo.org/10.5Responses_April-2020.pdf

16) Khan, H. (2020). Economic Impact of Covid 19 on Bangladesh : Agenda of Immadiate Action and Planning for the Future. 100380, 2-32.

https://mpra.ub.uni-muenchen.de/ 100380/

17) Leitheiser, E., Hossain, S. N., Sen, S., Moon, J., Tasnim, G., Knudsen, J. S., \& Rahman, S. (2020). Coronavirus on Supply Chains. April, 124. https://doi.org/10. 13140/RG. 2.2.18382.00329

18) Monitor, I. L. O. (2020). COVID-19 and the world of work: Impact and policy responses. March, 1-15.

https://www.ilo.org/wcmsp5/groups/public/---dgre ports/-dcomm/documents/briefingnote/wcms 7387 53.pdf

19) Nath, J., Chowdhury, A. F., \& Nath, A. K. (2020). Analyzing COVID-19 Challenges in Bangladesh. Preprints, August, 0-10. https://doi.org/10.20944/ preprints202007.0129.v1

20) Padhi, B., \& Triveni, T. (2020). Impact of COVID-19 on the tourism sector. Economic and Political Weekly, 55(30), 5.

https://www.epw.in/journal/2020/30/letters/impact -covid-19-tourism-sector.html

21) Panthhe, K. P., \& Kokate, C. N. (2021). Impact of Covid-19 on Tourism Sector in Nepal. Sustainability, Agri, Food and Environmental Research, 9(1), 43-52. https:// doi.org/ 10.7770/safer-v0n0-art2366
22) Rahman, M. R., Sajib, E. H., Chowdhury, I. M., Banik, A., Bhattacharya, R., \& Ahmed, H. (2021). Present scenario of covid-19 in Bangladesh and government preparedness for facing challenges. Journal of Advanced Biotechnology and Experimental Therapeutics, 4(2), 187-199. https://doi.org/10.5455/jabet.2021.d119

23) Ranasinghe, R., Damunupola, A., Wijesundara, S., Karunarathna, C., Nawarathna, D., Gamage, S., Ranaweera, A., \& Idroos, A. A. (2020). Tourism after Corona: Impacts of Covid 19 Pandemic and Way Forward for Tourism, Hotel and Mice Industry in Sri Lanka. SSRN Electronic Journal, https://doi.org/10.2139/ssrn.3587170

24) Reza, F., Kawsar, E., \& Mahabub, T. Bin. (2020). COVID-19 impact and responses : Bangladesh. April, pp-12.

25) Rume, T., \& Islam, S. M. D. U. (2020). Environmental effects of COVID-19 pandemic and potential strategies of sustainability. Heliyon, 6(9), e04965.

https://doi.org/10. 1016/j. heliyon.2020.e04965

26) Sakamoto, M., Begum, S., \& Ahmed, T. (2020). Vulnerabilities to COVID-19 in Bangladesh and a reconsideration of sustainable development goals. Sustainability (Switzerland), 12(13), 1-15. https://doi.org/10.3390/su12135296

27) Santos del Valle, A. (2020). the Tourism Industry and the Impact of Covid-19 Scenarios and Proposals. Global Journey Consulting, 34. https://worldshoppingtourism.com/downloads/GJ $\mathrm{C}$ The Tourism Industryand the Impact of $\mathrm{CO}$ VID_19.pdf

28) Schotte, S., Danquah, M., \& Osei, R. D. (2021). WIDER Working Paper 2021 / 27 The labour market impact of COVID-19 lockdowns Evidence from Ghana. February. https://www.wider.unu.edu/sites/default/files/Publi cations/Working-paper/PDF/wp2021-27-COVID-1 9-lockdowns-labour-market-impact-Ghana.pdf

29) Shammi, M. (2021). Strategic assessment of COVID-19 pandemic in Bangladesh : com-parative lockdown scenario analysis, public perception , 6148-6191. https://doi.org/10.1007/s10668-020-00867-y

30) Shetty, P. (2021). The Impact of COVID-19 in the Indian Tourism and Hospitality Industry: 
Brief Report. 10(456), 1-7.

https://www.longdom.org/open-access/the-impactof-covid19-in-the-indian-tourism-and-hospitality-i ndustry-brief-report-61261.html

31) Uğur, N. G., \& Akbıyık, A. (2020). Impacts of COVID-19 on global tourism industry: A crossregional comparison. Tourism Management Perspectives, 36(September), 100744. https://doi.org/10.1016/j.tmp.2020.100744

32) Vet, J. M. D. E., Ferrer, J. N., Gross, A., Kuehl, S., \& Flickenschild, M. (2021). Requested by the ITRE committee Im-pacts of the COVID-19 pandemic on EU industries.

https://www.europarl.europa.eu/thinktank/en/docu ment.html? reference=IPOL_STU(2021)662903
33) WEF, (2020). Challenges and opportunities in the post Covid-19 World. In World Econmic Forum Insight Report, 12(10).

https://www.weforum.org/reports/post-covid-19-ch allenges-and-opportunities

34) WHO, (2020). WHO Bangladesh COVID-19 Situation Report. $W H O, 10$.

https://www.who.int/bangladesh/emergencies/coro navirus-disease-(covid-19)-update/coronavirus-dis ease-(covid-2019)-ba ngladesh-situation-reports

35) World Health Organization, (2020). Covid-19 Situation Report. World Health Organization, 31(2), 61-66.

Citation: Mia MN., and Hassan K. (2021). Post COVID challenges to the tourism and hospitality industry: a study on Bangladesh, Can. J. Bus. Inf. Stud., 3(6), 109-119. https://doi.org/10.34104/cjbis.021.01090119 @ @ 